\section{Small Fragment Wounds : Biophysics, Pathophysiology and Principles of Management}

PF Hill, DP Edwards, GW Bowyer
Maj PF Hill M.Chir FRCS RAMC

Specialist Registrar in Trauma and

Orthopaedic Surgery

Royal Defence Medical College, Gosport,

Hampshire, PO12 2AB, U.K.

Maj DP Edwards ChM FRCS Ed RAMC

Specialist Registrar in General Surgery

Royal Defence Medical College, Gosport,

Hampshire, PO12 2AB, U.K.

Mr GW Bowyer M.Chir FRCS (Orth)

Consultant in Trauma and Orthopaedics

Southampton General Hospital, Southampton, SO16 6YD

\begin{abstract}
Military surgical doctrine has traditionally taught that all ballistic wounds should be formally managed by surgical intervention. There is now, however, both experimental and clinical evidence supporting the nonoperative treatment of selected small fragment wounds. Low energytransfer wounds affecting the soft tissues, without neuro-vascular compromise and with stable fracture patterns, may be suitable for early antibiotic treatment. The management of ballistic wounds to the gastrointestinal tract requires surgical intervention but, advances in the treatment of these wounds, especially those involving the colon, may allow more effective treatment with a reduced morbidity.
\end{abstract}

\section{Introduction}

The most common wounds in modern warfare are caused by fragmenting munitions such as artillery shells, mortar bombs and grenades, rather than bullets (Table 1) (Ryan et al 1991).

Table 1. Distribution of wounding agents in casualties for wars and campaigns this century (\%). (Ryan et al. 1991). Israeli figures are complicated by inclusion of psychiatric casualties in the group designated 'other'.

\begin{tabular}{llll}
\hline & \multicolumn{2}{l}{ Bullets } & \multicolumn{2}{l}{ Fragments Other } \\
\hline World War I & 39 & 61 & - \\
World War II & 10 & 85 & 5 \\
Korea & 7 & 92 & 1 \\
Vietnam & 52 & 44 & 4 \\
Borneo & 90 & 9 & 1 \\
Northern Ireland & 55 & 22 & 20 \\
Israel 1982 & 11.6 & 53 & 35.5 \\
Falkland Islands & 31.8 & 55.8 & 12.4 \\
\hline
\end{tabular}

Modern munitions aim to incapacitate soldiers by producing multiple wounds from very small fragments with low available kinetic energy (Figure 1). At the same time, the widespread use of personal body armour has altered the pattern of injury in the wounded and led to a predominance of multiple wounds to the limbs (Ryan et al 1991; Spalding et al 1991; Bowyer 1995) (Table 2).

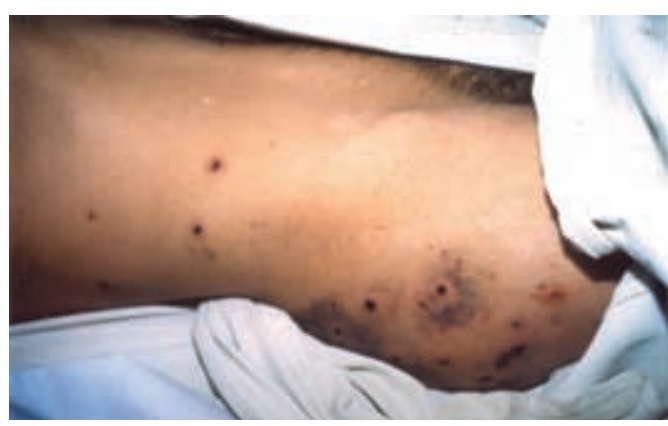

Fig 1. (a) (above) Multiple wounds by small fragments to the buttocks and abdomen of an Afghan fighter. (b) (below) The radiograph shows the size and distribution of the fragments in the pelvic area.

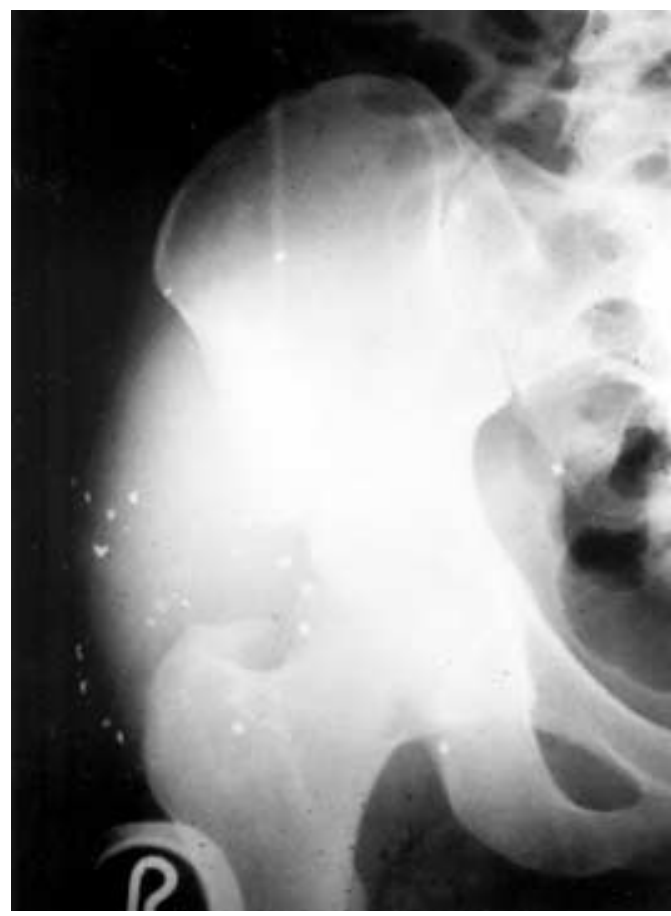

Table 2. Distribution of injuries in casualties at surgery (\%) (Ryan et al. 1991). Israeli figures are complicated by inclusion of psychiatric casualties in the group designated 'other'.

Head/ Chest Abdomen Limbs Other neck

\begin{tabular}{llllll}
\hline World War I & 17 & 4 & 2 & 70 & 7 \\
World War II & 4 & 8 & 4 & 75 & 9 \\
Korea & 17 & 7 & 7 & 67 & 2 \\
Vietnam & 14 & 7 & 5 & 54 & 20 \\
Borneo & 12 & 12 & 20 & 56 & - \\
Northern & 20 & 15 & 15 & 50 & - \\
Ireland & & & & & \\
Israel 1975 & 13 & 5 & 7 & 40 & 35 \\
Israel 1982 & 14 & 4 & 5 & 41 & 36 \\
Falkland & 14 & 7 & 12 & 67 & 1 \\
Islands & & & & &
\end{tabular}


The treatment of penetrating wounds involving only the soft tissues of limbs remains controversial. Previous military surgical doctrine dictated that, due to all missile wounds being bacterially contaminated, they should be managed surgically (Kirby \& Blackburn 1981). There is both clinical and experimental evidence that suggests a non-operative approach may be appropriate for some of these wounds (Bowyer et al 1995; Bowyer 1997), even when there are low energy fractures (Hill et al 1998).

Similarly there remains controversy regarding the management of colonic injuries, especially when they are due to low energy projectiles in the military casualty. Experience from civilian trauma centres has provided data to support the primary closure of the majority of colonic injuries produced by low energy missiles. There remains some hesitation as to the applicability of these protocols to the management of military colonic wounds.

This paper sets out the current understanding of the mechanisms of injury caused by small fragments. The limb wounds under consideration consist of skin, muscle and bony injury, with or without a stable fracture pattern; injuries to neuro-vascular structures are not considered. Abdominal wounds are those of the gastro-intestinal tract, without major vascular injury, although consideration is given to the management of associated wounds of the paralumbar muscles.

The current understanding of the biophysics and pathophysiology of these wounds is presented, along with the scientific evidence on which treatment regimen have been developed. Clinical evidence for the efficacy of non-operative regimen for limb wounds is also presented.

\section{MECHANISMS OF INJURY}

\section{Wounding Munitions}

Many modern fragment munitions are designed to produce multiple pre-formed (or partially pre-formed) fragments of a

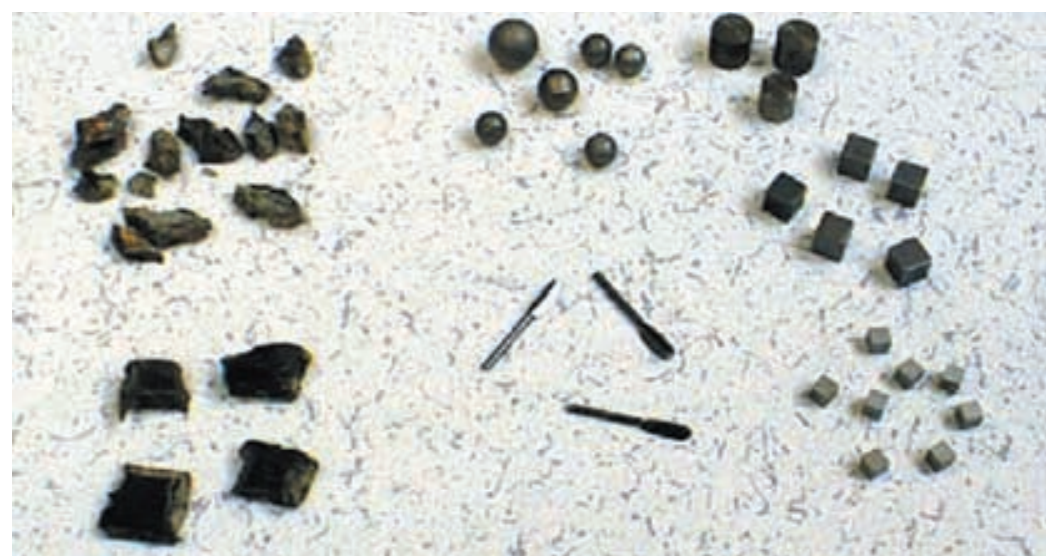

Fig 2. Types of pre-formed fragments for anti-personnel and anti-materiel use. The lower centre "fragments" are flechettes. consistent size that offer the optimum compromise between range, velocity, probability of a hit and injury characteristics (Figure 2). The fragments have a mass of between $0.1-0.2 \mathrm{~g}$ and diameter of about 2$3 \mathrm{~mm}$. Other exploding munitions may produce natural fragmentation particles which will vary in size from dust particles to metal pieces of mass greater than $20 \mathrm{~g}$ (French \& Callender 1962; Ryan et al. 1991). Initial velocities of the small fragments from both types of weapons will be very high $(<1500 \mathrm{~m} / \mathrm{s})$ but, because of their irregular shape, velocities will decline rapidly.

\section{Energy Transfer}

The available kinetic energy $(E)$ of a missile depends upon the mass $(m)$ and velocity $(v)$, according to the equation

$$
E=1 / 2 m v^{2}
$$

However, it is the amount of energy released to tissues, the energy transfer $(\Delta E)$, that determines the extent of injury, rather than the velocity of the projectile itself. As a consequence, high energy projectiles may produce low energy-transfer wounds. Energy transfer is also influenced by the tissues involved and projectile factors.

Ballistic wounds can be classified, according to the amount of energy causing them, into:

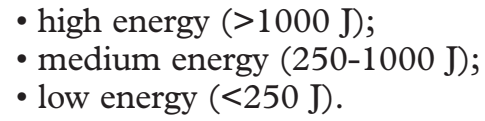

As this classification is arbitrary there are no distinct boundaries between the groups. There is a trend in the amount of tissue destruction occurring in each group, as greater energy transfer equates to an increase in the amount of tissue destruction. Fragment munitions tend to produce low energy-transfer wounds.

As the projectile passes through the tissues it creates a wound track, the diameter of which is larger than that of the projectile itself. There are several reasons for this: the projectile tumbles as it passes through the tissues; a temporary cavity forms along the path of the projectile and the projectile may break-up and form secondary projectiles (Sellier \& Kneubuehl 1994). When a projectile moves through a medium, the surrounding material is accelerated away from its path by the high pressures created around it (Woodruff 1898; Janzon 1983). This causes the formation of a temporary cavity behind the projectile, which is filled with air or vapour at sub-atmospheric pressure. Matter is sucked into this lowpressure cavity at the points of entry and exit (Dziemian \& Herget 1950; Thoresby \& Darlow 1967). At the moment of maximum expansion of the cavity, the energy transferred from the projectile causes rupture and laceration of the tissue as it retards the 


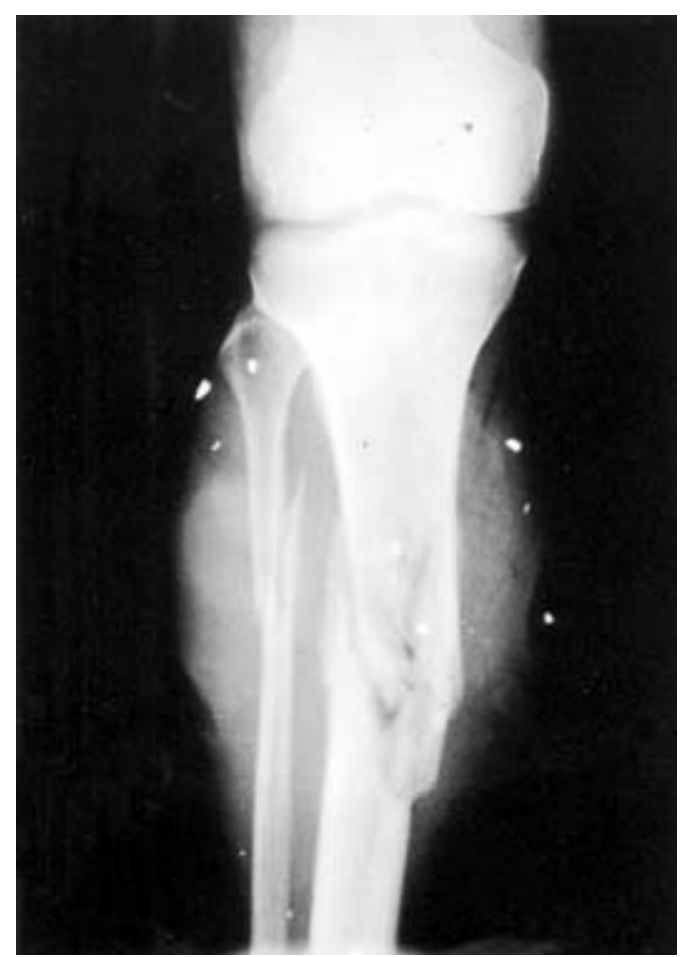

Fig 3. Comminuted bone fracture from multiple antipersonnel fragments.

projectile's passage. Structures close to the projectile pathway may be damaged due to the pressure waves and the stretching and displacement caused by the temporary cavity, leaving zones of contusion and concussion, devitalised tissue and haemorrhage within and between muscle fibres (Wang et al 1990). The temporary cavity leaves behind a smaller permanent cavity containing fragments of necrotic muscle and blood clot. Temporary cavitation does not always cause a large zone of tissue damage and skeletal muscle is relatively tolerant of the insult, especially with low energy transfer wounds.

Small fragment munitions are also capable of causing fracture of bone (Figure 3). Experimental studies have shown that the minimum impact velocity required to penetrate bone is in the order of $65 \mathrm{~m} / \mathrm{s}$ (Amato et al 1989; Loh \& Lee 1990). This is an approximation and is largely independent of the mass of the projectile. When a low energy projectile strikes cancellous bone, it causes either a divot or a hole (Rose et al 1988). Depending on the velocity of the fragment and the thickness of the bone at the point of impact, the lesion may involve one or both cortices. Where there is little cancellous bone, such as in the diaphysis of a long bone, even a low energy strike can cause comminution, often with a large butterfly fragment (Huelke \& Darling 1964).

\section{PATHOPHYSIOLOGY}

The clinical consequences of wounding will depend on several factors: the tissue or organ involved, the extent of the injury (tissue damage and contamination) and the treatment provided (Table 3).
Table 3. Factors contributing to clinical outcome following wounding.

\begin{tabular}{ll}
\hline $\begin{array}{l}\text { Factors determining } \\
\text { injury }\end{array}$ & Note \\
\hline Tissue/Organ injured & $\begin{array}{l}\text { Sensitivity of tissues to } \\
\text { injury and compensatory } \\
\text { mechanisms vary, for } \\
\text { example vascular injury and } \\
\text { muscle injury with similar } \\
\text { energy input will have very } \\
\text { different effects }\end{array}$ \\
$\begin{array}{l}\text { Extent of Tissue } \\
\begin{array}{l}\text { Eamage } \\
\text { Extent and Nature } \\
\text { of Contamination }\end{array}\end{array}$ & $\begin{array}{l}\text { Bacterial and foreign body } \\
\text { contamination of the } \\
\text { wound. }\end{array}$ \\
Medical Care & $\begin{array}{l}\text { Quality and timing of } \\
\text { intervention }\end{array}$ \\
\hline
\end{tabular}

The casualty with multiple small fragment wounds may have injuries which involve the eyes, arms and chest; each wound will have essentially the same order of magnitude of energy transfer, but the thoracic wound may be life threatening as a consequence of great vessel injury. The eye injuries may be expected to be immediately disabling whereas the limb wounds may be virtually unnoticed in the initial examination. The outcome for all of these wounds will depend on both the quality and timing of medical care.

\section{Contamination of Limb Wounds} Material Contamination

All war wounds are contaminated by a combination of soil, clothing and skin. Weapon fragments have been shown experimentally to cut clothing and skin and to transport these into the wound (Ryan 1990). High velocity fragments tend to shred clothing into finer pieces and a high energytransfer wound with a large temporary cavity will drive these particles throughout the temporary cavity so that contamination is dispersed widely away from the wound track (Ryan 1990). Contamination can be drawn into the wound from both the entry and exit wounds. By contrast, low energy transfer wounds will have limited contamination which is much closer to the wound track. Experimental studies of material contamination of small fragment wounds of muscle have shown that there is usually only minimal contamination of the track, with a few fibrils of material maximally distributed 2-3 cm along it (Bowyer et al 1995; Bowyer 1997).

\section{Bacterial Contamination}

The bacterial flora of a gunshot wound changes with time. Altemeier (1942) showed that the organisms found in wounds can be roughly divided into three groups.

1.Spore-bearing micro-organisms of faecal origin, such as the anaerobic gas forming bacteria Clostridium welchii and Clostridium tetani. 
2.Non-spore-bearing microbes of faecal origin such as the enterococci, proteus species and Escherichia coli.

3.Pyogenic cocci, including the streptococci and staphylococci.

Fleming (1915) described three phases occurring in the bacterial colonisation of war wounds. In the primary stage, which lasts about one week, sporulating anaerobes and streptococci are the predominant organisms. In the secondary phase, lasting two to three weeks, a gradual transition occurs between sporulating anaerobes and pyogenic cocci. The tertiary phase is characterised by the disappearance of the anaerobes, but persistence of pyogenic cocci.

More recent studies have demonstrated the high contamination rates of traumatic open wounds of limbs. Gustilo and Anderson (1976) found that $70 \%$ of open fractures had positive wound cultures before treatment, whilst Patzakis and Ivler (1977) reported that $62 \%$ of initial wound cultures were positive. Robinson et al (1989) prospectively studied the microbiological flora contaminating eighty-nine open fractures. Fifty-eight per cent of the fractures were caused by workrelated accidents and had only a moderate soft tissue injury. Wound cultures were positive in $83 \%$ of all fractures and a total of eighty-four strains of bacteria were isolated. In $39 \%$ of cultures, various species of aerobic Gram-negative rods were retrieved (most commonly Pseudomonas aeruginosa), whilst Staphylococcus epidermidis (35\%) and Staphylococcus aureus (26\%) accounted for the rest. Staphylococci, streptococci and clostridia, all organisms normally harboured by the soil and human skin, have been cultured from military uniforms (Tikka 1982).

\section{Natural History of Contamination}

All open wounds are invariably contaminated, yet only a few develop infection. This implies that in certain circumstances, the systemic and local host defence mechanisms are successful at preventing the bacteria from reaching the critical level necessary for infection. French surgeons during the First World War were the first to suggest that the number of bacteria might be important (Hepburn 1919). Wounds more than fifteen hours old were débrided, cultured and packed open. If the culture plates showed no streptococci and fewer than five colonies of other organisms, delayed closure was performed. Otherwise, the wounds were left open and allowed to heal by secondary intention. These observations went unnoticed and quantitative bacteriology was ignored until Elek (1956) demonstrated that $7.5 \times 10^{6}$ staphylococcal organisms were required to produce a pustule in human skin. Similar critical inoculum sizes were obtained by Cooney et al (1982), who, using quantitative microbiological assessments of upper extremity wounds, found that sepsis was unlikely to occur if the size of the inoculum was less than $10^{5}$ organisms per gram of tissue. Twenty out of twenty-four patients with bacterial counts greater than $10^{5}$ organisms per gram of tissue developed infection. The critical inoculum size of $10^{5}$ organisms per gram of tissue has been supported by other studies (Robson et al 1973; Marshall et al 1976).

Elek (1956) found that the number of bacteria necessary to cause infection was reduced ten thousand-fold in the presence of a foreign body, which was modelled by using a single suture placed with the inoculum. Zimmerli et al (1982) found that one hundred colony-forming units of Staphylococcus aureus were sufficient to cause infection in $95 \%$ of polymethylmethacrylate tissue cages implanted under the skin of guinea pigs. When the cages were not present, even the injection of $10^{8}$ organisms failed to produce a subcutaneous infection. These quantitative studies observed infection occurring in soft tissues, rather than bone. Bone is more resistant to primary infection and requires the addition of a fracture or necrosis or both, to increase its susceptibility to infection (Norden 1970).

Given favourable conditions, bacterial cells will multiply at a maximum rate which, when measured as the logarithm of the total number of cells, increases linearly with time (Thomas 1988). Therefore, the number of bacteria in a wound is time dependent. Consequently, wounds with a relatively small number of contaminants, given agreeable conditions for bacterial growth may, over a period of time, accumulate $10^{5}$ organisms per gram of tissue, which increases the likelihood of infection.

Robson et al (1973) studied bacterial counts in civilian wounds at various time intervals. Wounds that were treated within two hours of injury contained less than one hundred organisms per gram of tissue, whereas those that were treated within three hours contained $10^{2}-10^{5}$ organisms, whilst those that were treated up to five hours after injury contained more than $10^{5}$ organisms per gram of tissue. All of the patients developing a wound infection demonstrated greater than $10^{5}$ organisms per gram of tissue. Over half the patients with wounds containing greater than $10^{5}$ organisms developed an infection.

\section{Wound Excision}

Friedrich (1898) had shown in the nineteenth century that if contaminated wounds were excised within six hours of creation, infection could be prevented. Miles et al. (1957) postulated that there was a decisive period lasting three to four hours 
within which local defence mechanisms were able to prevent bacteria from establishing themselves. The cutaneous inflammatory response of the guinea pig to a variety of bacterial pathogens was investigated. It was found that, if at the time of inoculation local ischaemia was created by the injection of adrenaline or by the initiation of shock by dehydration, the maximum size attained by the local infective lesion was substantially increased. The greatest effect was seen if the enhancing agent was administered within two hours of inoculation. If it was introduced four to five hours after inoculation, the enhancing effect disappeared. This work was confirmed by Polk and Miles (1973), who used Escherichia coli to study the course of infection in the adductor muscle of mice. It was found that during the first few hours after inoculation, there was extensive killing of the bacteria by local defences, which ceased to operate after this period, and that the subsequent course of the local infection was determined by the number of bacteria surviving after this early decisive period.

To investigate the effect of differing lengths of time between wounding and débridement on the subsequent development of infection, Dahlgren et al (1981) produced fifty-four wounds in the thighs of pigs, without prior cleaning of the skin. Animals were divided into groups receiving wound débridement at either one, six or twelve hours after wounding and samples were taken after debridement from the wound margins, for bacteriological assessment. Heavy growth of bacteria in tissue samples was demonstrated in $11 \%$ of wounds six hours after infliction of trauma, but in $60 \%$ after a twelve hour delay. It was concluded that débridement should be performed within six hours to eradicate infection, as further delay allows the bacteria to become established.

\section{Fragment Injuries to \\ Gastro-intestinal Tract}

Bowel, being a soft tissue, if injured by small fragments behaves similarly to soft tissue wounds of the limbs. Low energy fragments will lose energy as they pass through the abdominal wall; however there may be sufficient energy retained for the projectile to penetrate one, or both walls of bowel, causing both entry and exit wounds. Rarely, a missile may stop within the lumen of the bowel or breech the full thickness of the bowel and cause a blunt visceral injury.

The available energy of these projectiles is low and the wounds in bowel are small and discrete with little surrounding visceral injury (Figure 4). In an experimental study using $200 \mathrm{mg}$ steel fragments fired at $200 \mathrm{~m} / \mathrm{s}$ into porcine colon, the mean diameter of wounds produced was $6.1 \mathrm{~mm}$ (Edwards 1998). There was almost no surrounding contusion, no mesenteric tearing and often little evidence of a colonic wound other than

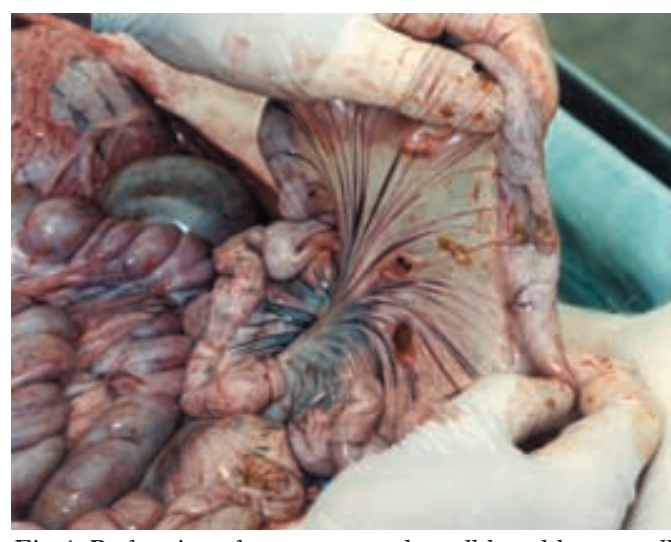

Fig 4. Perforation of mesentery and small bowel by a small anti-personnel fragment simulator. The wounds are small and discrete.

mucosa partially protruding through a serosal defect. The presence or absence of intraluminal faeces and /or air did not appear to influence the wound characteristics.

Penetrating injury of the bowel will invariably lead to contamination of adjacent tissues with luminal contents, comprising micro-organisms, food material (of varying degrees of digestion) and digestive enzymes. This will lead to peritonitis, extra-peritoneal infection and sepsis. Local contamination may have an adverse effect on the healing of bowel wounds (Irvin \& Hunt 1974), as well as predisposing to systemic illness. The priority in the management of bowel injuries must be to ensure no further displacement of bowel contents, either by the direct restoration of intestinal continuity and integrity, or by diverting the faecal stream to the body surface in the form of a stoma. The management of any exit wound track and its associated contamination remains controversial.

\section{Healing of Bowel Wounds}

Intra-abdominal trauma and infection readily create a local environment which is unfavourable for the healing of bowel (Irvin $\&$ Hunt 1974). The degree of primary trauma is related to the energy of the missile whereas secondary trauma is related to surgical mobilisation of the bowel and débridement of wound tracks. Irvin and Hunt demonstrated in rats that experimental colonic anastomoses had a significantly lower collagen content and tensile strength, and a higher rate of dehiscence, when performed over a paralumbar (psoas) muscle injury, compared with those performed over uninjured muscle (Irvin \& Hunt 1974). By contrast, remote trauma (of limbs) did not result in these anastomotic weaknesses. Intra-abdominal and retroperitoneal infections have similar detrimental effects on bowel protein synthesis; the strength of experimental colonic anastomoses was markedly reduced in the presence of peritonitis (Ahrendt et al 1996).

The management of a retroperitoneal 
wound track caused by a low energy fragment requires a balance to be struck between the removal of devitalised and contaminated tissue and the detrimental effects of creating further local trauma by débridement. Edwards et al (1999) aimed to quantify the degree of retrocolic trauma and risk of contamination caused by small fragments passing through the colon in an experimental study. Steel fragments (200mg) were fired at $200 \mathrm{~m} / \mathrm{s}$ through exteriorised porcine colon and caught in $20 \%$ gelatin. The fragments and resultant tracks were subjected to quantitative bacteriological examination to determine the extent of contamination. The median bacterial count for complete tracks was $1.2 \times 10^{4} \mathrm{cfu} / \mathrm{g}$. Counts were highest in the initial $10 \mathrm{~mm}$ of the track and then reduced along its length. In light of accepted clinical practice that casualties with penetrating bowel injury would receive antibiotic treatment, it was considered that data from this study did not support wound track excision in cases of retrocolic trauma following penetrating colonic injury. It was concluded that these procedures might only serve to increase local trauma and are therefore likely to prejudice colonic wound repair.

Although there is a large body of scientific data describing experimental colonic healing, few studies have examined the healing of multiple bowel wounds, especially in the presence of infection. At laparotomy in adult pigs, Edwards et al (1999) created multiple ballistic wounds of the colon using antipersonnel fragment projectiles. The colon was returned to the abdomen and colonic repair was performed at a second laparotomy, 6 hours after wounding. Colonic wounds were repaired using either a single layer of interrupted absorbable sutures, or stainless steel skin staples in lieu of sutures. Colonic wound healing was assessed clinically over a period of up to 14 days and at post-mortem, by biomechanical and histological examination. The healing of 209 colonic wounds in 18 pigs was assessed. There were 2 premature deaths due to sepsis. All repairs withstood intraluminal pressures in excess of physiological levels. There was no significant difference in the initial leak pressures of repairs using the two methods; however, histological examination showed stapled repairs healed more rapidly than sutured repairs. This study provided results to support definitive primary repair of colonic wounds caused by low energy missile fragments.

\section{MANAGEMENT OF LIMB WOUNDS}

Initial management of any limb wound must identify and treat any life-threatening injuries by established resuscitation methods (Gustilo et al 1990; Bowyer \& Rossiter 1998). It is important to assess for any concomitant vascular and neurological injuries in the injured limb (Barros D'Sa 1992).

\section{Conventional Wound Management}

The standard, or conventional, approach to ballistic wound management was developed from experiences in World War I and is based upon injuries caused by large fragments or bullets, and aimed at preventing wound infection. This consists of three distinct phases:

- early pre-operative wound care;

- surgical exploration of the wound;

- later closure or reconstruction of the wounded part.

The wound should be covered with a sterile dressing as soon as possible and left in place until the wound can be inspected in the operating theatre. Antibiotics play a critical role in preventing or delaying the onset of infection.

\section{Antibiotics}

Antibiotics play a role in preventing, or delaying, the onset of infection in ballistic wounds. Clostridia and beta-haemolytic streptococci have caused the major fatal infective complications of war wounds to limbs and antibiotic treatment has tended to rely on benzylpenicillin as the mainstay of the first line of treatment (Kirby \& Blackburn 1981; Mellor et al 1997). Penicillin has been associated with a reduction in the morbidity and mortality of war wounds and there is strong experimental evidence to support its continued use (Thoresby \& Matheson 1967; Mellor et al 1997). A ballistic fracture carries the additional risk of staphylococcal osteomyelitis and most pathogenic staphylococci are now resistant to benzylpenicillin. For this reason additional cover is needed with flucloxacillin or a cephalosporin (Mellor et al 1997).

Burke (1961) was the first to highlight the benefit of early administration of antibiotics. In a series of experiments using skin lesions in guinea pigs contaminated with Staphylococcus aureus, he found that as the time between injection of bacteria and the administration of penicillin increased, the effect of antibiotic decreased. The maximum antibiotic effect was observed when it was administered one hour before the wounds were inoculated. Penicillin injected more than three hours after the staphylococci were injected had no inhibitory effect on the size of the lesion.

In recent years a much less aggressive surgical approach, with non-operative management for simple low energy-transfer gunshot wounds has been reported from North America. Soft tissue wounds have been treated in some centres on an outpatient basis after wound irrigation. In one series of over 3000 patients, the overall infection rate was under $2 \%$ (Ordog et al 
1993). About $40 \%$ of these received antibiotic treatment, but the incidence of infection (mostly Staphylococcus aureus) was not significantly reduced by this.

Small fragment wounds to the soft tissues of the limbs have been successfully treated with antibiotics alone in a combat setting. This has been shown in multiple grenade fragment wounds managed in a Red Cross Hospital on the Thai-Cambodian border (Coupland 1993) and in a similar setting on the Afghan border (Bowyer 1997). There was a very low infection rate in small fragment wounds involving the soft tissues in patients managed with early antibiotics (penicillin). There is experimental work to support this approach (Bowyer 1997).

\section{Infection of Bone}

Bowers et al (1973) examined the effect of administration of cephaloridine on the development of bone infection in osteotomies of the canine femur. Staphylococcus aureus was injected into the marrow cavity and the cortex subsequently replaced. When cephaloridine was given preoperatively all wounds were sterile and did not become clinically infected but, when therapy was started six hours or later after contamination, infection occurred uniformly. No attempt was made to study the effect of antibiotics given at earlier time intervals.

More recently, Worlock et al (1988) produced evidence that the progressive diminution of antibiotic effect with time does not apply to experimental bone infections. An experimental model of post-traumatic osteomyelitis was developed using a fracture of the rabbit tibia contaminated with Staphylococcus aureus and stabilised with an intramedullary Kirschner wire. A single dose of cephradine was given at time intervals ranging from one hour before inoculation to four hours after inoculation. The frequency of osteomyelitis occurring in animals in the control group (no antibiotic) was $91 \%$. The maximum reduction in the rate of infection was seen when the antibiotics were given before the inoculation with bacteria (30\%), but antibiotics still produced a reduction in the infection rate if the first dose was delayed for up to four hours after inoculation (51\%). The antibiotic was as effective after four hours as it was after a delay of one hour. However, although this appeared to be a trend, the number of animals used in each group was only ten and a statistically significant difference in the infection rate was only seen in the group treated one hour before inoculation. Unlike Burke's observations in soft tissue wounds, no progressive reduction in the effect of antibiotics was found with increasing delay in administering the first dose.

Hill et al (1998) have shown that antibiotics can be effective in preventing the development of osteomyelitis in an undisplaced ballistic fracture not requiring stabilisation, if administered up to six hours after inoculation. Using a model of a ballistic fracture in the pig tibia, $10^{7} \mathrm{cfu}$ of Staphylococcus aureus were inoculated into the medullary canal and left for six hours. The animals were divided into two groups. Animals in the treatment group received intramuscular flucloxacillin and penicillin for five days, whilst those in the non-treatment group received no antibiotic treatment. All the animals in the non-treatment group developed osteomyelitis, whilst none in the treatment group developed disease.

Patzakis et al (1974) demonstrated a significant reduction in infection rates when open fractures were treated with high dose cephalosporins. A prospective study was undertaken to evaluate the use of antibiotics in the treatment of open fractures. Three hundred and ten patients were divided into groups receiving either penicillin and streptomycin, cephalothin or no antibiotics and the incidence of infection was found to be $13.9 \%$ in the control group, $9.7 \%$ in the group receiving penicillin and streptomycin and $2.3 \%$ in the group receiving cephalothin alone. There was a significant difference in the infection rate between the control group and those receiving cephalothin, but not between the control group and those receiving penicillin and streptomycin. The location of the fracture within the body, the age and gender of the patients and the mechanism of injury (direct trauma versus gunshot wound) were evenly distributed between the groups. Antibiotic therapy was started three hours from the time of injury and after bacteriology swabs had been taken. All open fractures were surgically débrided and each wound was irrigated with ten litres of $0.9 \%$ saline. Most patients had nonoperative fixation of their fracture. Eight patients required immediate internal fixation, whilst twenty-eight required delayed internal fixation ten to twenty-one days after injury. These patients were evenly distributed between the groups. However, the severity of the injuries was not classified, so a criticism of this study is that no comparison could be made between the groups regarding this variable. Sixty per cent of the organisms cultured from the wounds of the patients treated with penicillin and streptomycin were resistant to the antibiotics compared to $20 \%$ of the organisms in the group treated with cephalothin.

Gustilo and Anderson (1976) advocated the routine use of high doses of intravenous antibiotics in the treatment of open fractures. One thousand and twenty-five open fractures of long bones were studied, of which 673 were studied retrospectively and 352 prospectively. The infection rate was found to be $2.5 \%$ in the prospective group. However, there was no control group for comparison that did not receive antibiotics, and so it is 
difficult to be certain that antibiotic therapy contributed to the clinical result. Fractures with less soft tissue trauma (Gustilo Types I and II) had a lower infection rate than those that were Type III.

In a further study, Patzakis and Wilkins (1989) studied the factors influencing the infection rate in open fractures. Seventyseven infections in 1104 open fracture wounds occurring over an eleven year period were evaluated to identify those factors that predisposed to infection. The single most important factor in reducing the infection rate was the early administration of antibiotics providing antibacterial activity against both Gram-positive and Gramnegative micro-organisms.

Carefully selected civilian gunshot wounds involving bone have also been successfully treated by early wound irrigation, dressing, antibiotics and splintage (Hansraj et al 1995). These fractures, typically caused by lowenergy hand gun bullets or shotgun pellets were typified by minimal bony and soft tissue damage with negligible displacement or devitilisation of bone fragments. They are seen in very large numbers in civilian practice in the US, where they are treated at many centres with simple wound cleansing and oral antibiotics. No surgical exploration was performed and patients were not usually admitted to hospital. Rose et al (1988) reported a retrospective study of twelve patients with either a drill hole or divot fracture of a long bone treated with local wound care and antibiotics only. There were no cases of infection. Marcus et al (1980) retrospectively compared the results of formal surgical débridement with débridement of the wound margins only and administration of antibiotics, and found no difference in the infection rates $(3.8 \%$ versus $4.2 \%$ respectively).

\section{Selection of Limb Wounds for Non-Operative Management}

Having set out the case for non-operative management of selected limb wounds, it is important to consider how such wounds might be identified.

Risk factors for infection identified in the North American series from trauma centres, (Ordog et al 1993) included:

- a prolonged time between wounding and presentation for treatment (all $>24 \mathrm{hr}$, mean $>3$ days);

- lack of basic wound cleansing before attendance;

- wound size between 1 and $2 \mathrm{~cm}$;

- failure to comply with wound care instructions;

- low to medium energy transfer fractures. These are similar to the criteria used by others, working in military environments, in deciding whether non-operative management might be appropriate (Coupland 1993;
Bowyer 1997). Essentially these wounds should:

- be small, with entry/exit no more than $1 \mathrm{~cm}$;

- show no evidence of permanent cavitation within the wound;

- have no neuro-vascular compromise;

- not be associated with a compartment syndrome;

- have a stable fracture pattern;

- have no signs of infection;

- be treated early (by dressing and antibiotics).

These decisions require the surgeon to rely on the state of the wound track, inferred from the size and extent of the entry and exit wounds, considered together with the length of the wound track and the radiographic appearances such as the spread of the bony fragments. In some cases assessment of the soft tissue wound may require surgical exploration and hence, operative management.

A major concern in military surgery is how to distinguish those wounds that can be managed with non-operative treatment with prompt antibiotic cover, from those which require operation. In certain centres with clinical experience, the non-surgical approach may be a safe and efficient use of resources. However, thorough assessment of the injuries may require surgical exploration. If there is any doubt about the amount of non-viable tissue in the missile track, safe management requires formal operative exploration and débridement.

The default position should be to operate on any limb wounds in which there is any doubt about tissue viability, or where the casualty has had a delay between wounding and treatment. Associated injuries to neurovascular structures, swelling and the risk of compartment syndrome, or an unstable fracture pattern, will all mandate surgery. The luxury of observing a patient for several days to observe whether a wound infection develops may not be possible if early evacuation is required, in a military scenario.

\section{THE MANAGEMENT OF GASTRO-INTESTINAL WOUNDS}

\section{Stomach and Small Intestine}

The stomach and small intestine are relatively sterile and have an extremely good blood supply. The operative management of traumatic perforation of the upper gut is well accepted: repair with or without resection and thorough peritoneal lavage (Guarino et al 1995). Repair of the retroperitoneal duodenum, particularly with associated pancreatic injury can be troublesome and may require a limited resection, or diversion with a Roux loop or gastrojejunostomy (for anatomical rather than pathophysiological considerations). The identification of all 
perforations caused by fragmenting munitions is essential, as a missed wound will result in continued leakage of enteric content and persisting intra-abdominal infection.

\section{Colon}

The bacterial contents of faeces, spilled at the time of colonic wounding, inevitably results in faecal peritonitis, leading in turn to sepsis. As a consequence, penetrating colonic injury is associated with a relatively high morbidity and mortality.

The treatment options for managing colonic wounds fall into two categories. Firstly exteriorisation of the colon with:

- colostomy;

- colostomy after resection of devitalised colon;

- proximal colostomy to defunction a distal repair or anastomosis, or

- exteriorisation of a repaired colonic wound.

Alternatively, the colon may be repaired primarily, either as a direct repair or by resection and anastomosis.

Exteriorisation became the standard protocol after World War II following the advice of Ogilvie (1944). The premise was that, if the faecal stream was diverted to the exterior, there was no risk of further peritoneal contamination as a result of possible colonic anastomotic failure. This surgical standard has been questioned, both experimentally and clinically.

Four randomised trials compared colostomy with primary colonic repair in the civilian management of colonic trauma (Chappuis et al 1991; Falcone et al 1992; Sasaki et al 1995; Gonzalez et al 2000). The injuries were caused by road traffic accidents and gunshot wounding (representing high energy transfer injuries), as well as shotgun and stab wounds (similar to low energy transfer wounds). Complication rates were used as the prime method of comparison. Details of the results are shown in Table 4.

There were no significant differences between treatment groups with regard to age, sex, time delay from injury to surgery and mechanism of injury. Gunshot wounds were the most common forms of injury in all series (68\%-93\% of patients). These studies reported that primary colonic repair was associated with a lower overall complication rate than colostomy, despite higher Penetrating Abdominal Trauma Index scores for the primary repair groups. In none of the series did a primary colonic wound repair dehisce, whereas Chappuis et al reported three anastomotic failures despite proximal stoma and Sasaki et al reported two colostomy complications (a prolapse and a stomal necrosis). Moreover, there were only 4 deaths in all the series, 1 death in the primary repair group reported by Falcone et $a l$ and Gonzalez et al reported 2 deaths in the primary repair group and 1 in the colostomy group.

Exteriorised colonic repair, popularised by Okies et al (1974) in the early 1970's was a compromise procedure whereby a colonic wound was repaired but brought to the skin as a closed colostomy. When the patient had recovered and the colonic wound was seen to have healed, the colon was returned to the peritoneal cavity a week or two after wounding. This technique was limited to the treatment of a single colonic wound. Recent data supporting primary intraperitoneal colonic repair have consigned this technique to surgical history.

\section{Rectum}

Penetrating injury to the rectum occurs in two distinct patterns. Firstly, projectiles from fragmenting munitions can impact upon the front of the torso causing intraperitoneal trauma including injury to the intraperitoneal and (rarely) extraperitoneal rectum. Secondly, the rectum is at risk from antipersonnel landmines, where the characteristic pattern of injury includes the perineum. The anal sphincters and the extraperitoneal rectum are particularly vulnerable.

Wounds of the intraperitoneal rectum can be managed as colonic wounds. Anal sphincter injuries need repair; this is best achieved as a delayed procedure, therefore anal sphincter injury management should include a proximal defunctioning stoma. The optimum surgical treatment of extraperitoneal rectal injuries without anal sphincter damage is less clear. Options include simply a proximal stoma, the addition of rectal mobilisation from the abdomen with repair of the rectum, and

Table 4. Prospective, randomised trials comparing primary colonic repair with colostomy in the management of colonic injury.

\begin{tabular}{|c|c|c|c|c|c|}
\hline Author & $\begin{array}{c}\text { Total } \\
\text { Patients }\end{array}$ & $\begin{array}{c}\text { Low } \\
\text { energy } \\
\text { wounds }\end{array}$ & $\begin{array}{l}\text { Number of } \\
\text { patients per } \\
\text { treatment } \\
\text { group }\end{array}$ & $\begin{array}{l}\text { Number (\%) } \\
\text { Complications }\end{array}$ & Deaths \\
\hline $\begin{array}{l}\text { Chappuis et al } \\
1991\end{array}$ & 56 & 5 & $\begin{array}{ll}\text { Primary Repair } & 28 \\
\text { Colostomy } & 28\end{array}$ & $\begin{array}{l}10(36 \%) \\
18(64 \%)\end{array}$ & $\begin{array}{l}0 \\
0\end{array}$ \\
\hline $\begin{array}{l}\text { Falcone et al } \\
1992\end{array}$ & 22 & 3 & $\begin{array}{ll}\text { Primary Repair } & 11 \\
\text { Colostomy } & 11\end{array}$ & $\begin{array}{c}8(73 \%) \\
10(91 \%)\end{array}$ & $\begin{array}{l}1 \\
0\end{array}$ \\
\hline $\begin{array}{l}\text { Sasaki et al } \\
1995\end{array}$ & 71 & 9 & $\begin{array}{ll}\text { Primary Repair } & 43 \\
\text { Colostomy } & 28\end{array}$ & $\begin{array}{c}8(19 \%) \\
10(36 \%)\end{array}$ & $\begin{array}{l}0 \\
0\end{array}$ \\
\hline $\begin{array}{l}\text { Gonzalez et al } \\
2000\end{array}$ & 176 & 15 & $\begin{array}{lr}\text { Primary Repair } & 89 \\
\text { Colostomy } & 87\end{array}$ & $\begin{array}{l}16(18 \%) \\
18(21 \%)\end{array}$ & $\begin{array}{l}2 \\
1\end{array}$ \\
\hline
\end{tabular}


possibly, the use of rectal washout and presacral drains (Levy et al 1995). There are no randomised data to support any one of these options. However, Ivatury et al (1991) selected $63 \%$ of extraperitoneal rectal injuries for treatment without repair and found no increase in pelvic infection, compared to those selected for repair.

Presacral drainage has not been shown to be of benefit in civilian rectal trauma. In a military practice, Armstrong et al (1973) found a $50 \%$ reduction in pelvic infection when presacral drainage was used. Of all the therapeutic options for rectal wound management distal rectal washout (DRW) is the most controversial, due to the fear that lavage fluid may extravasate within perirectal tissues and increase the risk of local infection. No benefit was found by Burch et al (1989) when they used DRW in 50\% of (pre-selected) patients in civilian practice. Shannon et al (1988) found a decreased rate of septic complications in patients who had DRW and, in the military setting, Laverson and Cohen (1971), writing from the Vietnam War, reported a reduction of morbidity from $72 \%$ to $10 \%$ when DRW was employed.

Recent military practice appears to have followed civilian, rather than military, evidence. Two series from the Bosnia-Croatia War (Kovacic et al 1994; Stankovovic et al 1996) reported 42 extraperitoneal rectal injuries managed without DRW and presacral drainage, and all except three employed a proximal colostomy. Clearly, evidence from controlled trials is required to answer this controversial area of general trauma surgery.

\section{SUMMARY}

Small fragment, low energy-transfer wounds are likely to increase in future military conflicts, invariably causing increased morbidity, rather than mortality. Wounds may affect any body region, although a predominance of limb wounds is predicted. There is both experimental and clinical evidence that limb wounds may be managed effectively by non-surgical protocols, although careful patient selection is required along with the recognition that, in some cases, surgical intervention will be required, often as part of the initial wound assessment. Small fragment injuries to the bowel will require surgical intervention and the potential for multiple wounding and the development of sepsis, must influence the surgical approach to the patient. Results from clinical and experimental studies have provided increasing support for the primary repair of certain colonic wounds, despite the presence of local infection, although this regimen has yet to be formally adopted into military doctrine.

\section{References}

Ahrendt GM, Tantry US, Barbul A. Intra-abdominal sepsis impairs reparative collagen synthesis. Am $\mathcal{F}$ Surg 1996; 171: 102-7.

Altemeier WA. The bacteriology of war wounds. Int Abst Surg 1942;518-33.

Amato JJ, Syracuse D, Seaver PR et al Bone as a secondary missile: an experimental study in fragmenting of bone by high velocity missiles. F Trauma 1989;29:609-12.

Armstrong RG, Schmitt HJ, Patterson LT. Combat wounds of the extraperitoneal rectum. Surgery 1973; 74: 570-4.

Barros D'Sa AAB. Complex vascular and orthopaedic limb injuries. F Bone foint Surg 1992;74-B:176-8.

Bowers WH, Wilson FC, Greene WB. Antibiotic prophylaxis in experimental bone infections. F Bone foint Surg 1973;55-A:795-807.

Bowyer GW. Afghan war wounded-application of the Red Cross wound classification. F Trauma 1995; 38:647.

Bowyer GW. The management of small fragment wounds in modern warfare - a return to Hunterian principle? Ann R C S Eng 1997;79:175-82.

Bowyer GW, Cooper GJ, Rice P. Management of small fragment wounds in war: current research. Ann $R C S$ Eng 1995;77:131-4

Bowyer GW, Rossiter ND. Management of gunshot wounds of the limbs. [Instr Course Lect]. $\mathcal{F}$ Bone foint Surg 1997;79-B:1031-6.

Burch JM, Feliciano DV, Mattox K. Colostomy and drainage for civilian rectal injuries: is that all? Ann Surg 1989; 209: 600-10.

Burke JF. The effective period of preventative antibiotic action in experimental incisions and dermal lesions. Surgery 1961;50:161-8.

Chappuis CW, Frey DL, Dietzen CD et al Management of penetrating colon injuries; a prospective randomised trial. Ann Surg 1991; 213: 492-

Cooney WP, Fitzgerald RH, Dobyns JH et al Quantitative wound cultures in upper extremity trauma. F Trauma 1982;22:112-7.

Coupland RM. War Wounds of Limbs- Surgical Management. Oxford: Butterworth-Heinemann Ltd: 1993.

Dahlgren B, Berlin R, Brandberg A et al Bacterial findings in the first twelve hours following experimental missile trauma. Acta Chir Scand 1981;147:513-8.

Dziemian AJ, Herget CM. Physical aspects of the primary contamination of bullet wounds. Milit Surg 1950;106:294-9.

Edwards DP. Primary repair of multiple colonic injuries. [Ch M Thesis]: Manchester: Manchester Univ.; 1998.

Edwards DP, Brown D, Watkins PE. Should colon penetrating small missiles be removed? An experimental study of bacterial contamination of fragment simulating projectiles and retrocolic wound tracks. F Invest Surg 1999; 12: 25-9.

Edwards DP, Warren BF, Galbraith KA et al Comparison of techniques for the repair of experimental colonic perforations. Brit F Surg 1999; 86: 514-7.

Elek SD. Experimental Staphylococcal infections in the skin of man. Ann NY Acad Sci 1956;65:85.

Falcone RE, Wanamaker SR, Santanello SA et al. Colorectal trauma: Primary repair or anastomosis with intracolonic bypass vs. ostomy. Dis Col Rectum 1992; 35: 957-63.

Fleming A. On the bacteriology of septic wounds. Lancet 1915;2:638-43.

French RW, Callender GR. Ballistic characteristics of wounding agents. In Heaton LD, Coates JB, Beyer JC, eds. Wound Ballistics. Washington. Office of the Surgeon General, 1962;91-141.

Friedrich PL. Die aseptische Versorgung frischer Wunden unter Mitteilung von Their-Versuchen uber Auskeimungszeit in frischen Wunden. Arch Klin Chir 1898;57:288-310. 
Gonzalez RP, Falimirski ME, Holevar MR. Further evaluation of colostomy in penetrating colon injury. Am Surg 2000; 66: 342-6.

Guarino J, Hassett JM, Luchette FA. Small bowel injuries: Mechanisms, patterns and outcome. F Trauma 1995; 39: 1076-80.

Gustilo RB, Anderson JT. Prevention of infection in the treatment of one thousand and twenty-five open fractures of long bones. F Bone Foint Surg 1976;58A:453-8.

Gustilo RB, Merkow RL, Templeman D. The management of open fractures. I Bone foint Surg 1990;72-A:299-304.

Hansraj KK, Weaver LD, Todd AO. et al Efficacy of ceftriaxone versus cefazolin in the prophylactic management of extra-articular cortical violation of bone due to low-velocity gunshot wounds. Orthop Clin North Am 1995;26:9-17.

Hepburn HH. Delayed primary suture of wounds. BMF 1919;1:181-3

Hill PF, Brown D, Galbraith KA et al. The delayed treatment of ballistic fractures with antibiotics. Transactions of the 44th Annual Meeting Orthopedic Research Society, 1998 Mar 16-19, New Orleans, Louisiana. p. 282

Huelke DF, Darling H. Bone fractures produced by bullets. F Forensic Sci 1964;9:461-9.

Irvin TT, Hunt TK. The effect of trauma on colonic healing. Brit f Surg 1974; 61: 430-436.

Ivatury R, Licata J, Gunduz Y et al. Management options in penetrating rectal injuries. Am Surg 1991; 57: $50-55$.

Janzon B. High energy missile trauma. A study of the mechanisms of wounding of muscle. Gothenburg: Engalls Väg; 1983. p.147-63.

Kirby G, Blackburn G. Field Surgery Pocket Book. London: Her Majesty's Stationary Office; 1981.

Kovacic D, Lovric Z, Kondza G. War injuries of the colon and rectum. Unfallchirurg 1994; 97: 378-381.

Laverson GS, Cohen A. Management of rectal injuries. Am $\mathcal{F}$ Surg 1971; 122: 226-230.

Levy RD, Strauss P, Aladgem D et al. Extraperitoneal rectal gunshot injuries. F Trauma 1995; 38: 273-277.

Loh Y, Lee JS. Study of pig femoral fractures in vitro induced by missiles. F Trauma (China) 1990;6 Suppl:79-81.

Marshall KA, Edgerton MT, Rodeheaver GT et al. Quantitative microbiology: its application to hand injuries. Am f Surg 1976;131:730-3.

Mellor SG, Easmon CSF, Sanford JP. Wound contamination and antibiotics. In Ryan JM, Rich NM, Dale RF, Morgans BT, Cooper GJ, eds. Ballistic Trauma. London. Edward Arnold, 1997;61-71.

Miles AA, Miles EM, Burke J. The value and duration of defence reactions of the skin to the primary lodgement of bacteria. Br F Exp Path 1957;38:79-96.

Norden CW. Experimental osteomyelitis. I. A description of the model. F Infect Dis 1970;122:410-18. Ogilvie WH. Abdominal wounds in the western desert. Surg Gynecol Obstet 1944; 78: 225-238.

Okies JE, Bricker DL, Jordan GL et al. Exteriorized primary repair of colonic injuries. Am f Surg 1972; 124: $807-10$

Ordog GJ, Sheppard GF, Wasserberger JS et al. Infection in minor gunshot wounds. F Trauma 1993;34:358-65.

Patzakis MJ, Harvey JP, Ivler D. The rôle of antibiotics in the management of open fractures. F Bone foint Surg 1974;56-A:532-41.
Patzakis MJ, Ivler D. Antibiotic and bacteriological considerations in open fractures. South Med $\mathcal{F}$ 1977;70:46-8

Patzakis MJ, Wilkins J. Factors influencing infection rate in open fracture wounds. Clin Orthop 1989;243:36-40

Polk HC, Miles AA. The decisive period in the primary infection of muscle by Escherichia coli. Br f Exp Path 1973;54:99-109.

Robinson D, Hadas N, Halperin N et al. Microbiologic flora contamination open fractures: its significance in the choice of primary antibiotic agents and the likelihood of deep wound infection. 7 Orthop Trauma 1989;4:283-6.

Robson MC, Duke WF, Krizek TJ. Rapid bacterial screening in the treatment of civilian wounds. I Surg Res 1973;14:426-30.

Rose SC, Fujisaki CK, Moore EE. Incomplete fractures associated with penetrating trauma: aetiology, appearance and natural history. F Trauma 1988;28:106-

Ryan JM. An enquiry into the nature of infection in fragment wounds. [MS Thesis]: Dublin: University College Dublin 1989.

Ryan JM, Cooper GJ, Haywood IR et al. Field surgery on a future conventional battlefield: strategy and wound management. Ann $R$ Coll Surg Engl 1991;73:13-20

Sellier KG, Kneubuehl BP. Wound ballistics and the scientific background. Amsterdam: Elsevier, 1994.

Sasaki LS, Allaben RD, Golwala R et al. Primary repair of colon injuries: A prospective randomized study. $\mathscr{f}$ Trauma 1995; 39: 895-901.

Shannon FL, Moore EE, Moore FA. Value of distal colon washout in civilian rectal trauma reducing gut bacterial translocation. F Trauma 1988; 28: 989-94 Spalding TJW, Stewart MPM, Tulloch DN et al. Penetrating missile injuries in the Gulf war 1991. Br F Surg 1991;78:1102-4

Stankovic N, Petrovic M, Drinkovic N et al. Colon and rectal war injuries. F Trauma 1996; 40: S183-S188.

Thomas CGA. Medical microbiology. 6th ed. London: Baillière Tindall; 1988

Thoresby FP, Darlow HM. The mechanisms of primary infection of bullet wounds. $\mathrm{Br} F \mathrm{Surg}$ 1967;54:359-61.

Thoresby FP, Matheson JM. Gas gangrene of the high velocity missile wound. II: an experimental study of penicillin prophylaxis. F R Army Corps 1967;113:36-9. Tikka S. The contamination of missile wounds with special reference to early antimicrobial therapy. Acta Chir Scand [Suppl] 1982;508:281-7.

Wang DW, Liu XT, Wang CR et al. The effect of injury to organs adjacent to the wound channel in 44 swine shot with steel balls and 22 wounded soldiers. F Trauma (China) 1990;6 Suppl:101-4.

Woodruff CE. The causes of the explosive effect of modern small calibre bullets. NY Med F 1898;67:593601.

Worlock P, Slack R, Harvey L, et al. An experimental model of post-traumatic osteomyelitis in rabbits. $\mathrm{Br} \mathcal{F}$ Exp Path 1988;69:235-44

Zimmerli W, Waldovogel FA, Vaudaux $\mathrm{P}$ et al. Pathogenesis of foreign body infection: description and characteristics of an animal model. $\mathcal{F}$ Infect $D$ is 1982;146:487-97. 